\title{
Isolation and characterization of a crude oil degrading bacteria from formation water: comparative genomic analysis of environmental Ochrobactrum intermedium isolate versus clinical strains**
}

\author{
Lu-jun CHAI ${ }^{\S 1}$, Xia-wei JIANG ${ }^{\S 2}$, Fan ZHANG $^{1}$, Bei-wen ZHENG $^{\dagger \ddagger 2}$, Fu-chang SHU $^{3}$, Zheng-liang WANG ${ }^{3}$, \\ Qing-feng $\mathrm{CUI}^{4}$, Han-ping DONG ${ }^{4}$, Zhong-zhi ZHANG ${ }^{5}$, Du-jie $\mathrm{HOU}^{1}$, Yue-hui SHE ${ }^{\dagger 3}$ \\ $\left({ }^{1}\right.$ Key Laboratory of Marine Reservoir Evolution and Hydrocarbon Accumulation Mechanism, \\ School of Energy Resources, China University of Geosciences, Beijing 100083, China) \\ $\left({ }^{2}\right.$ State Key Laboratory for Diagnosis and Treatment of Infectious Diseases, the First Affiliated Hospital, \\ School of Medicine, Zhejiang University, Hangzhou 310003, China) \\ $\left({ }^{3}\right.$ College of Chemistry and Environmental Engineering, Yangtze University, Jingzhou 434023, China) \\ $\left({ }^{4}\right.$ Institute of Porous Flow \& Fluid Mechanics, Chinese Academy of Sciences, Langfang 065007, China) \\ ( ${ }^{5}$ State Key Laboratory of Heavy Oil Processing, China University of Petroleum, Beijing 257061, China) \\ †E-mail: zhengbw@zju.edu.cn; sheyuehui@163.com \\ Received Jan. 26, 2015; Revision accepted July 6, 2015; Crosschecked Sept. 17, 2015
}

\begin{abstract}
In this study, we isolated an environmental clone of Ochrobactrum intermedium, strain 2745-2, from the formation water of Changqing oilfield in Shanxi, China, which can degrade crude oil. Strain 2745-2 is aerobic and rod-shaped with optimum growth at $42{ }^{\circ} \mathrm{C}$ and pH 5.5. We sequenced the genome and found a single chromosome of 4800175 bp, with a G+C content of $57.63 \%$. Sixty RNAs and 4737 protein-coding genes were identified: many of the genes are responsible for the degradation, emulsification, and metabolizing of crude oil. A comparative genomic analysis with related clinical strains (M86, 229E, and LMG3301 ${ }^{\top}$ ) showed that genes involved in virulence, disease, defense, phages, prophages, transposable elements, plasmids, and antibiotic resistance are also present in strain $2745-2$.
\end{abstract}

Key words: Comparative genome, Ochrobactrum intermedium, Oil degradation, Pathogen doi: 10.1631 /jzus.B1500029

Document code: A

CLC number: X172

\section{Introduction}

Oil contamination is a worldwide problem, which is growing more serious with economic development; its effects are long lasting and remediation is difficult.

\footnotetext{
* Corresponding authors

$\S$ The two authors contributed equally to this work

* Project supported by the National High-Tech R \& D Program (863) of China (No. 2013AA064402), the National Natural Science Foundation of China (Nos. 81301461 and 51474034), the Zhejiang Provincial Natural Science Foundation of China (No. LQ13H190002), and the Scientific Research Foundation of Zhejiang Provincial Health Bureau (No. 2012KYB083), China

(1D ORCID: Bei-wen ZHENG, http://orcid.org/0000-0002-7690-372X (c) Zhejiang University and Springer-Verlag Berlin Heidelberg 2015
}

Several methods of oil degradation have been developed, the method with the longest history being land farming, which is "low-tech" but timeconsuming (Genouw et al., 1994). Physical methods such as surface heating are more efficient but energyconsuming (Edelstein et al., 1994). Microbial oil degradation shows promise of being sustainable and environmentally friendly, and the screening of potential oil degrading microorganisms is becoming increasingly important. Bacteria from different habitats, such as soil (Jesubunmi, 2014; Kumar et al., 2014; Pham et al., 2014) and the ocean (Hazen et al., 2010; Hassanshahian et al., 2014), are screened for their oil degrading properties. These bacteria are then 
used individually or in a mixture (Creencia et al., 2014; Silva et al., 2015).

In our previous studies, several strains of bacteria, which have the ability to degrade crude oil, were isolated from the formation water of Chinese oilfields (She et al., 2011; 2014; Zhang et al., 2012; 2014; Zheng et al., 2014). In this study, we isolated from the Changqing oilfield a strain which has rarely been isolated from an oilfield, Ochrobactrum intermedium strain 2745-2. O. intermedium was first described in 1998 with five strains formerly known as members of Ochrobactrum anthropi (Holmes et al., 1988; Velasco et al., 1998). The name, O. intermedium, indicates an intermediate position between $O$. anthropi and Brucella spp. (Velasco et al., 1998). $O$. anthropi is an emerging opportunistic pathogen in immunocompromised patients (Mudshingkar et al., 2013) and members of Brucella are pathogens causing brucellosis which is a common zoonotic infection globally (Dean et al., 2012). Strains of O. intermedium are associated with both human beings and the environment. Some strains are pathogens which cause infection (Möller et al., 1999; Apisarnthanarak et al., 2005); some live in environments polluted by chromium (Kavita and Keharia, 2012), lead (Waranusantigul et al., 2011), and tobacco waste (Yuan et al., 2007), etc.

As a human pathogen and environmental bacterium, $O$. intermedium attracts a lot of interest. From a database survey, we found three draft genome sequences within $O$. intermedium, two of which (strains M86 and 229E) have been published (Kulkarni et al., 2013; 2014). Strains M86, 229E, and LMG3301 ${ }^{\mathrm{T}}$ were isolated from a stomach biopsy and blood taken from a non-ulcer dyspeptic individual from India. Thus, all of these three strains are associated with humans; no environmental strain had been sequenced before our study. Comparative genomic analysis is needed between human and environmental isolates of $O$. intermedium to give us a better understanding of the mechanisms by which it adapts to its environment.

Here, we describe the classification and features of $O$. intermedium strain $2745-2$, together with its genome sequence and the comparative genomic study we conducted with its clinical relatives, strains $\mathrm{LMG}_{3301}{ }^{\mathrm{T}}, 229 \mathrm{E}$, and M86. The aims of this work are to investigate the oil-degrading genes of strain
2745-2 and to find the distinction and similarities among the genomes and genes that reflect adaptation to specific environments.

\section{Materials and methods}

\subsection{Sampling and isolation of oil degrading bacteria}

A water sample was collected from an oilproducing well in Changqing oilfield, Shanxi Province, China, in 2012. The sample was stored immediately at $4{ }^{\circ} \mathrm{C}$. Oil degrading bacteria were isolated using sterile crude oil as the medium. After incubation, the culture was spread on LB agar plates containing $5.0 \mathrm{~g} / \mathrm{L}$ yeast extract (Difco, USA), $10.0 \mathrm{~g} / \mathrm{L}$ $\mathrm{NaCl}, 10.0 \mathrm{~g} / \mathrm{L}$ tryptone, and $20.0 \mathrm{~g} / \mathrm{L}$ agar (Difco, USA) to select the single clones. One strain (2745-2) was further characterized. It was cultured in LB medium and genomic DNA was extracted using QIAamp DNA Mini Kit (Qiagen, Germany) following the manufacturer's instructions. 16S ribosomal RNA (rRNA) was amplified by polymerase chain reaction (PCR) using the primers as follows: 27F (5'-AGA GTT TGA TCC TGG CTC AG-3') and 1492R (5'-GGT TAC CTT GTT ACG ACT T-3').

\subsection{Phylogenetic tree construction}

16S rRNA nucleotide sequence analysis was conducted using the BLASTN program against the national center for biotechnology information (NCBI)-nucleotide collection (nr/nt) database. Sequences were aligned by the CLUSTALW (Larkin et al., 2007). A Neighbor-Joining phylogenetic tree based on the Tamura-Nei model was constructed using MEGA6 software (Tamura et al., 2013).

\subsection{Characterization of strain 2745-2}

Cell morphology of strain 2745-2 was examined using a scanning electron micrograph (Quanta 200, FEI Co., USA). The temperature range, $\mathrm{pH}$ range, and $\mathrm{NaCl}$ range for growth were determined using methods described before (Cheng et al., 2015). Gram-reaction was carried out according to Bergey's manual (Holt et al., 1994). Tests for $\mathrm{H}_{2} \mathrm{~S}$ production and indole production were conducted using the method described by Mata et al. (2002). Hydrolase of starch, gelatin, and casein were tested. Single carbon source utilization tests were performed using 
D-glucose, maltose, lactose, D-galactose, rhamnose, raffinose, sorbitol, glycerol, cellobiose, sucrose, tetradecane, and hexadecane. Resistance to ampicillin, erythromycin, tetracycline, kanamycin, and gentamicin were tested.

\subsection{Whole genome sequencing}

Strain $2745-2$ was cultivated aerobically in LB medium, pH 5.5 at $42{ }^{\circ} \mathrm{C}$ overnight. Genomic DNA was extracted using the method described by Marmur and Doty (1962). The resulting genomic DNA was then measured using gel electrophoresis $0.7 \%(7 \mathrm{~g} / \mathrm{L})$ agarose with $\lambda$-Hind III digest DNA as the marker (TaKaRa, Dalian, China). The concentration of the genomic DNA was measured by NanoDrop ${ }^{\mathrm{TM}} 1000$ spectrophotometer (Thermo Fisher Scientific Inc., USA). Genomic DNA sequencing was performed using Illumina HiSeq2000 with Solexa paired-end sequencing strategy. One DNA library (500 bp insert size with Illumina adapter at both ends) was generated and detected by Agilent DNA analyzer 2100 (Agilent Technologies, USA).

\subsection{Sequence assembly and annotation}

Clean reads were assembled into scaffolds using the Velvet version 1.2.07 (Zerbino and Birney, 2008). We then used PAGIT flow (Swain et al., 2012) to prolong the initial contigs and correct sequencing errors.

The transfer RNAs (tRNAs) and rRNAs were identified using tRNAscan-SE (Lowe and Eddy, 1997), RNAmmer (Lagesen et al., 2007), and Rfam database (Griffiths-Jones et al., 2003; Burge et al., 2012). The genome annotation was predicted using the RAST server online (Aziz et al., 2008). Predicted genes were blast against the Clusters of Orthologous Groups (COGs) database (Tatusov et al., 2000; 2001). We applied the PHAST program to predict the prophages and putative phage-like elements in the genome (Zhou et al., 2011).

\subsection{Comparative genomic analysis}

The genome sequences of $O$. intermedium M86, 229E, and $\mathrm{LMG}_{3} 301^{\mathrm{T}}$ were downloaded from the NCBI database under the accession numbers AOGE00000000.1, ASXJ00000000.1, and ACQA 00000000.1, respectively (Kulkarni et al., 2013; 2014). All these genomes were annotated by the RAST on-line server, which was also used for sub- system annotations (Aziz et al., 2008). Contigs were re-ordered using the Mauve program (Darling et al., 2010). Blasts of the three genomes together with strain 2745-2 were performed using the BLAST+ program (Camacho et al., 2009). The BLAST Ring Image Generator (BRIG) was used for genome alignment visualization (Alikhan et al., 2011).

\subsection{Nucleotide sequence accession number}

The genome sequence of $O$. intermedium 2745-2 has been deposited in GenBank with the accession number JFHY00000000.1.

\section{Results}

\subsection{Phylogenetic analysis and characterization of strain 2745-2}

Neighbor-Joining phylogenetic analysis indicated the taxonomic status of $2745-2$, which is clearly classified into the same branch as $O$. intermedium LMG3301 ${ }^{\mathrm{T}}$. Rhizobium leguminosarum IAM $12609^{\mathrm{T}}$ was used as an out group (Fig. 1).

Strain 2745-2 was capable of growing at $15-45^{\circ} \mathrm{C}$ and $\mathrm{pH}$ 5.5-9.0 with optimum conditions being $42{ }^{\circ} \mathrm{C}$ and $\mathrm{pH}$ 5.5. Cells are straight rods, 0.6$0.9 \mu \mathrm{m}$ in diameter and 1.7-5.3 $\mu \mathrm{m}$ long (Fig. 2). Colonies grown at $42{ }^{\circ} \mathrm{C}$ on LB agar plate are gray, circular, and convex. $\mathrm{H}_{2} \mathrm{~S}$ and indole are produced. Gelatin and casein are hydrolyzed, but not starch. Lactose, rhamnose, tetradecane, and hexadecane are used as the carbon source, while D-glucose, maltose, D-galactose, raffinose, sorbitol, glycerol, cellobiose, and sucrose are not used. An antimicrobial susceptibility test showed that strain $2745-2$ is resistant to ampicillin, erythromycin, tetracycline, kanamycin, and gentamicin.

\subsection{Genome features}

The draft genome size of $O$. intermedium 2745-2 was 4800175 bp with a $\mathrm{G}+\mathrm{C}$ content of $57.62 \%$. The draft genome contains 4737 coding sequences (CDSs) and 60 RNAs including two complete rRNA operons. Detailed information on the genome is summarized in Table 1. A total of 4285 genes were categorized into COGs functional groups (Fig. 3). Five prophage regions have been identified (Fig. 4), including one intact, two incomplete, and two questionable regions (Table 2). 


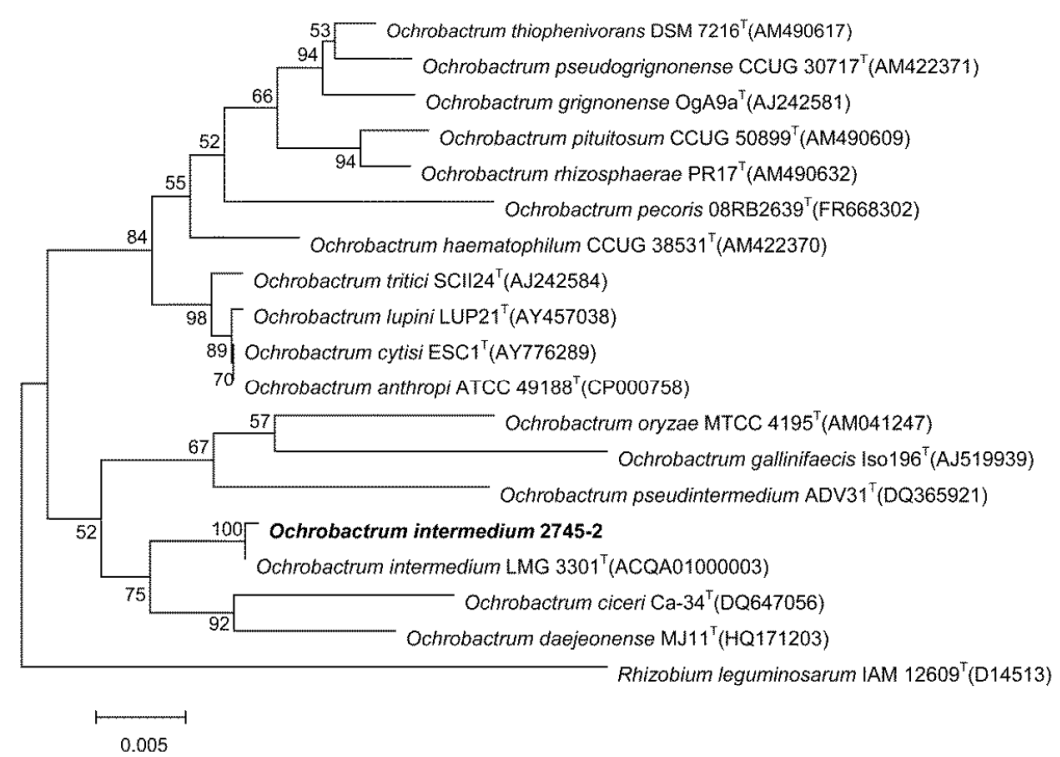

Fig. 1 Phylogenetic tree presenting the position of Ochrobactrum intermedium strain 2745-2

GenBank accession numbers for 16S rRNA genes of the strains used in this phylogenetic tree are shown following the organism names. The bootstrap values on the branching nodes were calculated on 1000 replications. Rhizobium leguminosarum IAM $12609^{\mathrm{T}}$ was used as an out group. The scale bar indicated 0.005 substitutions per nucleotide position

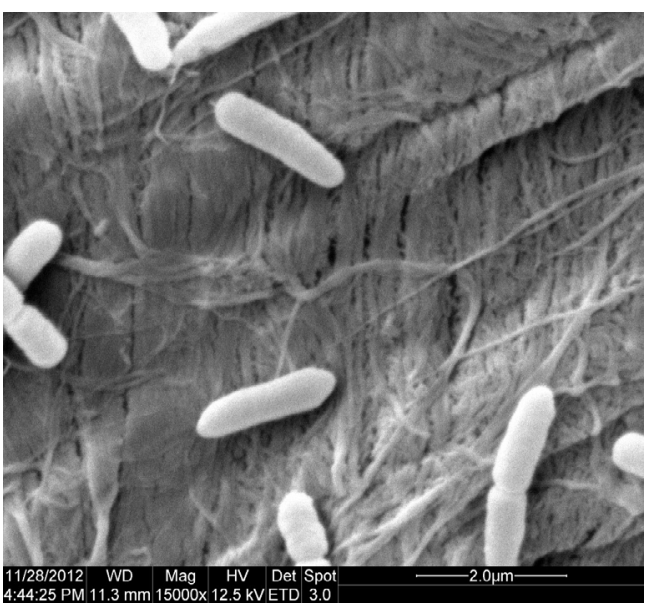

Fig. 2 Scanning electron micrograph of cells of Ochrobactrum intermedium strain 2745-2

Cells were grown at $42{ }^{\circ} \mathrm{C}$ in LB broth for $16 \mathrm{~h}$ (about early stationary phase)

\subsection{Comparative genomic analysis}

Comparative genomic analyses of $O$. intermedium M86, 229E, LMG3301 ${ }^{\mathrm{T}}$, and 2745-2 were conducted. The isolation source and genomic statistics are shown in Table 3. Comparisons of subsystem features between the four genomes revealed some distinctions between 2745-2 and the other three strains (Table 4). The numbers of genes involved in virulence, disease, and defense were significantly lower in 2745-2 than in the other strains. Genes involved in secondary metabolism were higher in 2745-2. This difference in gene numbers may be due to the different habitat of 2745-2. BLAST of nucleotide sequence between 2745-2 and the other three strains was performed and the identities were visualized (Fig. 5).

Table 1 Detailed information of the draft genome sequence of Ochrobactrum intermedium strain 2745-2

\begin{tabular}{ccccccc}
\hline \multirow{2}{*}{$\begin{array}{c}\text { Size } \\
(\mathrm{bp})\end{array}$} & $\begin{array}{c}\text { G+C content } \\
(\mathrm{bp})\end{array}$ & $\begin{array}{c}\text { Coding region } \\
(\mathrm{bp})\end{array}$ & Total & RNA & Protein-coding & COGs \\
\cline { 4 - 7 } 4800175 & 2766132 & 4145190 & 4797 & 60 & 4737 & 4285 \\
\hline
\end{tabular}

Table 2 Summary of prophage regions in strain 2745-2

\begin{tabular}{cclcl}
\hline Region & Region length $(\mathrm{kb})$ & Completeness & CDS & \multicolumn{1}{c}{ Specific keyword } \\
\hline 1 & 51.0 & Intact & 47 & Terminase, portal, plate, tail \\
2 & 10.3 & Incomplete & 16 & Tail \\
3 & 35.3 & Questionable & 32 & Integrase, terminase, portal, head, capsid \\
4 & 40.1 & Questionable & 54 & Terminase, portal, head, capsid, tail \\
5 & 15.5 & Incomplete & 20 & Terminase, capsid, head, tail \\
\hline
\end{tabular}




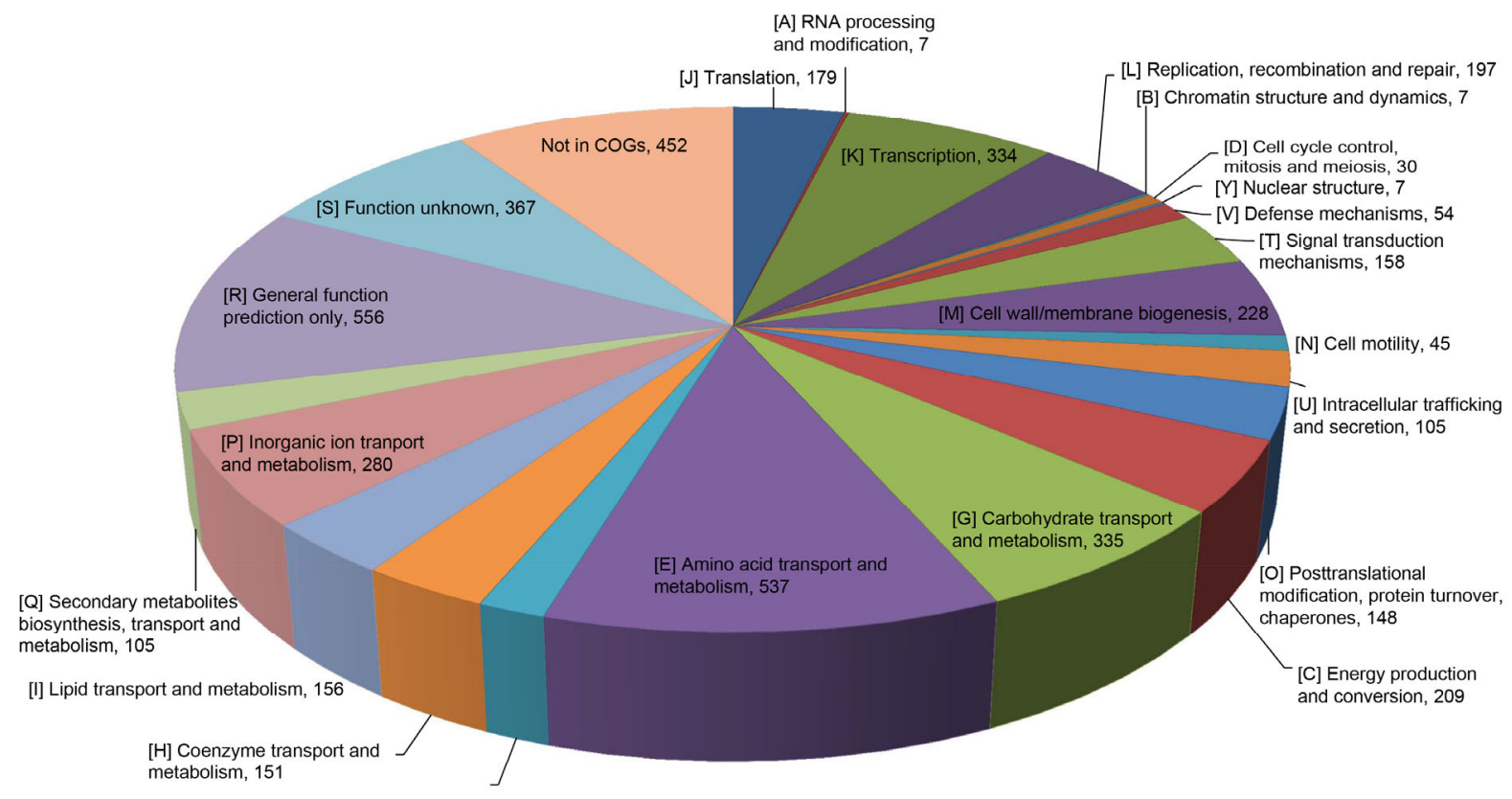

[F] Nucleotide transport and metabolism, 80

Fig. 3 Distribution of the genes associated with COG functional categories in Ochrobactrum intermedium strain 2745-2

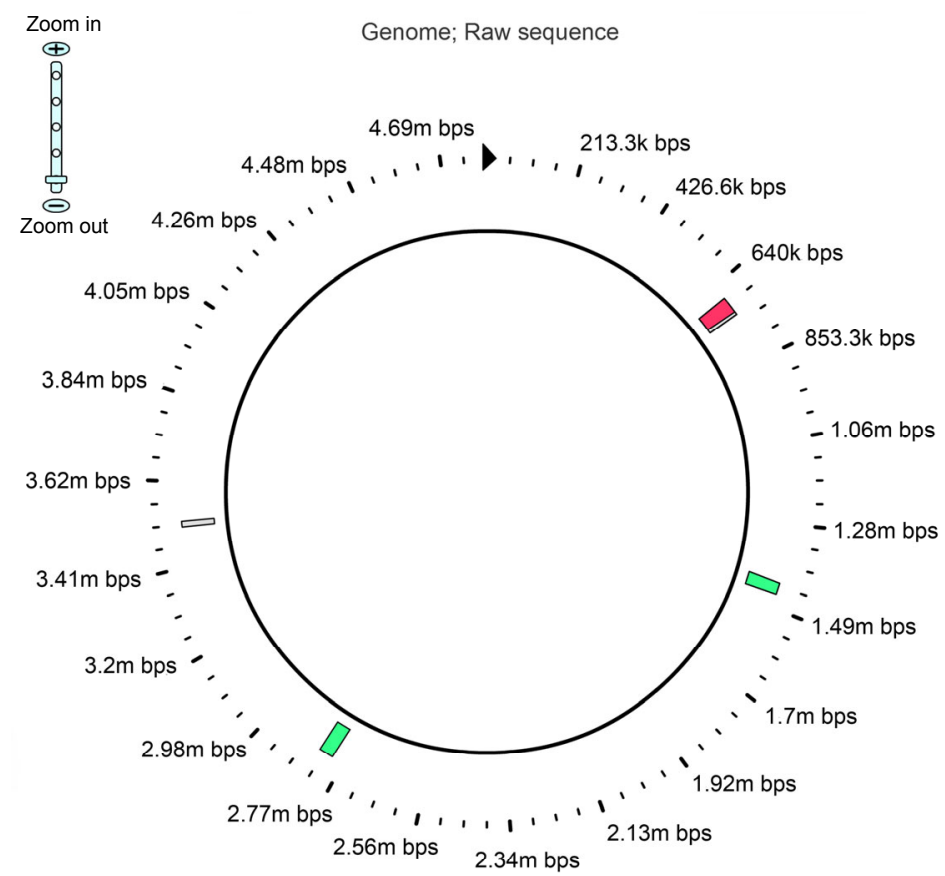

Accession: N/A

Length: 4800 175bps; Phages: 5

Prophage types

$\square$ Intact prophage

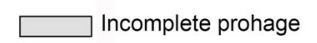
Questionable prophage

Fig. 4 Genomic view of prophage regions identified in the genome of strain 2745-2 
Table 3 Comparison between the genome statistics of four strains of Ochrobactrum intermedium

\begin{tabular}{lcccccccc}
\hline \multicolumn{2}{c}{ Strain } & $\begin{array}{c}\text { Isolation } \\
\text { source }\end{array}$ & Accession No. & Size (Mb) & GC (\%) & \multicolumn{3}{c}{ Number } \\
\cline { 6 - 8 } $2745-2$ & $\begin{array}{c}\text { Formation } \\
\text { water }\end{array}$ & JFHY00000000.1 & 4.80 & 57.6 & 95 & 440 & 4737 & 60 \\
M86 & $\begin{array}{c}\text { Gastric } \\
\text { biopsy }\end{array}$ & AOGE00000000.1 & 5.19 & 57.9 & 148 & 480 & 5473 & 66 \\
$229 \mathrm{E}$ & $\begin{array}{c}\text { Stomach } \\
\text { biopsy }\end{array}$ & ASXJ00000000.1 & 4.81 & 57.9 & 378 & 468 & 5610 & 58 \\
LMG3301 $^{\mathrm{T}}$ & Blood & ACQA00000000.1 & 4.73 & 57.7 & 4 & 474 & 4723 & 70 \\
\hline
\end{tabular}

Table 4 Comparisons between subsystem features of four strains of Ochrobactrum intermedium

\begin{tabular}{|c|c|c|c|c|}
\hline \multirow{2}{*}{ Subsystem feature } & \multicolumn{4}{|c|}{ Number of genes } \\
\hline & $2745-2$ & M86 & $229 \mathrm{E}$ & LMG3301 $^{\mathrm{T}}$ \\
\hline Cofactors, vitamins, prosthetic groups, pigments & 224 & 276 & 305 & 275 \\
\hline Cell wall and capsule & 111 & 107 & 134 & 111 \\
\hline Virulence, disease, and defense & 77 & 102 & 112 & 94 \\
\hline Potassium metabolism & 15 & 18 & 24 & 17 \\
\hline Photosynthesis & 0 & 0 & 0 & 0 \\
\hline Miscellaneous & 55 & 63 & 76 & 63 \\
\hline Phages, prophages, transposable elements, plasmids & 19 & 38 & 0 & 15 \\
\hline Membrane transport & 180 & 254 & 281 & 226 \\
\hline Iron acquisition and metabolism & 41 & 55 & 80 & 56 \\
\hline RNA metabolism & 127 & 145 & 189 & 157 \\
\hline Nucleosides and nucleotides & 100 & 109 & 121 & 110 \\
\hline Protein metabolism & 207 & 273 & 305 & 265 \\
\hline Cell division and cell cycle & 16 & 30 & 30 & 28 \\
\hline Motility and chemotaxis & 77 & 84 & 78 & 88 \\
\hline Regulation and cell signaling & 70 & 82 & 84 & 75 \\
\hline Secondary metabolism & 9 & 4 & 4 & 4 \\
\hline DNA metabolism & 98 & 123 & 124 & 107 \\
\hline Fatty acids, lipids, and isoprenoids & 113 & 153 & 169 & 153 \\
\hline Nitrogen metabolism & 35 & 38 & 51 & 38 \\
\hline Dormancy and sporulation & 2 & 2 & 3 & 1 \\
\hline Respiration & 126 & 134 & 157 & 134 \\
\hline Stress response & 119 & 131 & 146 & 128 \\
\hline Metabolism of aromatic compounds & 30 & 32 & 42 & 32 \\
\hline Amino acids and derivatives & 409 & 522 & 618 & 503 \\
\hline Sulfur metabolism & 11 & 54 & 65 & 54 \\
\hline Phosphorus metabolism & 43 & 53 & 57 & 49 \\
\hline Carbohydrates & 440 & 496 & 580 & 484 \\
\hline
\end{tabular}

\section{Discussion}

\subsection{Crude oil degradation related genes}

Crude oil is a mixture of hydrocarbons of various molecular weights. Many bacteria in nature have been found to be capable of degrading crude oil (Dawar and Aggarwal, 2015; Lincoln et al., 2015), using it as their sole carbon source. Strain $2745-2$ is one of them.
Experiments showed that this strain can use tetradecane and hexadecane, the main compounds in crude oil, as its carbon source. Tetradecane and hexadecane are alkanes which can be oxidized by alkane hydroxylases, such as AlkB and P450. Two alkB genes and one P450 gene were found in the genome of 2745-2. alkB encodes a protein named alkane 1-monooxygenase, which is the key enzyme in the degradation of alkanes. Genes encoding for 2-polyprenylphenol hydroxylase 


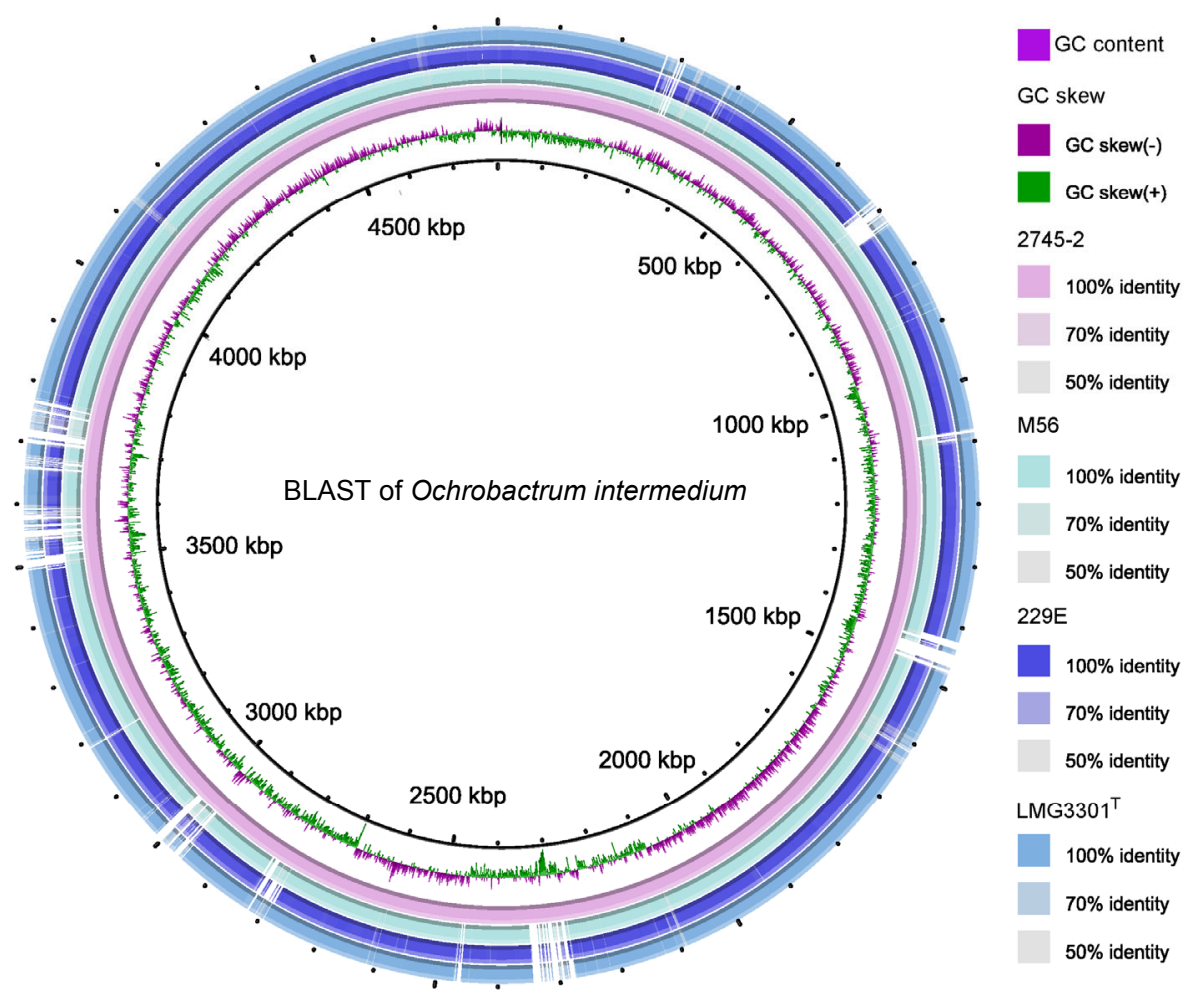

Fig. 5 BLAST visualization of Ochrobactrum intermedium genomes The rings illustrate a shared identity with the four strains

and alkaline phosphatase, which are responsible for degrading aminobenzoate, were found in the genome. Genes of 2-haloalkanoic acid dehalogenase and alcohol dehydrogenase for chloroalkane and chloroalkene degrading exist in the genome. Furthermore, 2745-2 also contains all genes involved in the assembly of flagella which allows the bacterium to move to the oil-water interface the degradation process. Many other oil-degrading bacteria also have suits of flagella assembly-related genes and it is believed that these genes can also benefit emulsification of the hydrocarbon in crude oil (Das et al., 2015). Strain 2745-2 also contains genes encoding for phosphomannomutase, acyl transferase, glycosyl transferase, rhamnosyltransferase, glucose-1-phosphate thymidylyltransferase, dTDP-glucose 4,6-dehydratase, dTDP-4-dehydrorhamnose 3,5-epimerase, dTDP-4dehydrorhamnose reductase, and $N$-acyl-L-homoserine lactone synthase. These enzymes are involved in the synthesis of rhamnolipids, a class of glycolipid, which work as bacterial surfactants by reducing the surface tension, critical micelle concentration, and interfacial tension, and increasing the emulsification and solubility of hydrocarbons in mixtures such as crude oil (Das et al., 2015). All these genes reflect the ability of strain 2745-2 to degrade crude oil.

\subsection{Pathogen potential of strain 2745-2}

Previous studies on the genome of two strains, O. intermedium M86 and 229E, identified many gene clusters related to virulence (Kulkarni et al., 2013; 2014). In our study, the genomes of three strains of $O$. intermedium, which are available in the public database (M86, 229E, and $\mathrm{LMG} 3301^{\mathrm{T}}$ ), were compared with the genome of strain 2745-2. All the strains have an average genomic size of $4.8 \mathrm{Mb}$ except M86 (Table 3). 2745-2 is an environmental strain and the other three are clinical. There are fewer genes involved in virulence, disease, and defense in strain 2745-2 compared with the others (Table 4). However, 
2745-2 contains several genes that are related to phages, prophages, transposable elements, and plasmids. Furthermore, we identified five prophage regions in 2745-2. One region is an intact phage with a length of $51 \mathrm{~kb}$, which encodes for phage-like and hypothetical proteins (Fig. 4). It is believed that the phage-like sequences improve the cell adhesion and the ability to acquire antibiotic resistance, properties that can enable bacteria to survive in new environments and become pathogens (Casjens, 2003; Zhou et al., 2011). The clinical isolates of $O$. intermedium, which are related to pathogens such as $O$. anthropi and Brucella spp., display a high level of resistance to forms of $\beta$-lactam antibiotics (Teyssier et al., 2005) and are considered to be pathogens. Although 2745-2 was isolated from a non-clinical environment, it was found to be resistant to ampicillin and the genomic annotation results showed the presence of several $\beta$-lactamase genes that provide resistance to $\beta$-lactam antibiotics. With all these properties, strain 2745-2 may have the potential to be a pathogen.

\section{Conclusions}

As the first environmentally-derived strain of $O$. intermedium whose genome has been sequenced, strain $2745-2$ is giving us a new perspective on its adaption to the environment. Genes involved in crude oil degradation are annotated in its genome, reflecting its ability to degrade crude oil. Further comparative genomic studies between 2745-2 and strains isolated from clinical samples will give us a better understanding of the adaption and evolution of environmental bacteria into host pathogens.

\section{Compliance with ethics guidelines}

Lu-jun CHAI, Xia-wei JIANG, Fan ZHANG, Bei-wen ZHENG, Fu-chang SHU, Zheng-liang WANG, Qing-feng CUI, Han-ping DONG, Zhong-zhi ZHANG, Du-jie HOU, and Yue-hui SHE declare that they have no conflict of interest.

This article does not contain any studies with human or animal subjects performed by any of the authors.

\section{References}

Alikhan, N.F., Petty, N.K., Zakour, N.L.B., et al., 2011. BLAST Ring Image Generator (BRIG): simple prokaryote genome comparisons. BMC Genomics, 12(1):402. [doi:10.
$1186 / 1471-2164-12-402]$

Apisarnthanarak, A., Kiratisin, P., Mundy, L.M., 2005. Evaluation of Ochrobactrum intermedium bacteremia in a patient with bladder cancer. Diagn. Micr. Infec. Dis., 53(2):153-155. [doi:10.1016/j.diagmicrobio.2005.05.014]

Aziz, R.K., Bartels, D., Best, A.A., et al., 2008. The RAST Server: rapid annotations using subsystems technology. BMC Genomics, 9(1):75. [doi:10.1186/1471-2164-9-75]

Burge, S.W., Daub, J., Eberhardt, R., et al., 2012. Rfam 11.0: 10 years of RNA families. Nucleic Acids Res., 41(D1): D226-D232. [doi:10.1093/nar/gks1005]

Camacho, C., Coulouris, G., Avagyan, V., et al., 2009. BLAST+: architecture and applications. BMC Bioinformatics, 10(1): 421. [doi:10.1186/1471-2105-10-421]

Casjens, S., 2003. Prophages and bacterial genomics: what have we learned so far? Mol. Microbiol., 49(2):277-300. [doi:10.1046/j.1365-2958.2003.03580.x]

Cheng, H., Zhang, S., Huo, Y.Y., et al., 2015. Gilvimarinus polysaccharolyticus $\mathrm{sp}$. nov., an agar-digesting bacterium isolated from seaweed, and emended description of the genus Gilvimarinus. Int. J. Syst. Evol. Microbiol., 65(Pt 2): 562-569. [doi:10.1099/ijs.0.065078-0]

Creencia, A.R., Mendoza, B.C., Migo, V.P., et al., 2014. Degradation of residual jatropha oil by a promising lipase-producing bacterial consortium. Philipp. J. Sci., 143(1):73-78.

Darling, A.E., Mau, B., Perna, N.T., 2010. ProgressiveMauve: multiple genome alignment with gene gain, loss and rearrangement. PLoS ONE, 5(6):e11147. [doi:10.1371/ journal.pone.0011147]

Das, D., Baruah, R., Roy, A.S., et al., 2015. Complete genome sequence analysis of Pseudomonas aeruginosa N002 reveals its genetic adaptation for crude oil degradation. Genomics, 105(3):182-190. [doi:10.1016/j.ygeno.2014.12. 006]

Dawar, C., Aggarwal, R.K., 2015. Draft genome sequence of hydrocarbon-degrading Pseudomonas putida strain KG-4, isolated from soil samples collected from KrishnaGodavari Basin in India. Genome Announc., 3(3): e00590-e00615. [doi:10.1128/genomeA.00590-15]

Dean, A.S., Crump, L., Greter, H., et al., 2012. Global burden of human brucellosis: a systematic review of disease frequency. PLoS Negl. Trop. Dis., 6(10):e1865. [doi:10. 1371/journal.pntd.0001865]

Edelstein, W., Iben, I., Mueller, O., et al., 1994. Radiofrequency ground heating for soil remediation: science and engineering. Environ. Prog., 13(4):247-252. [doi:10. 1002/ep.670130413]

Genouw, G., de Naeyer, F., van Meenen, P., et al., 1994. Degradation of oil sludge by landfarming - a case-study at the Ghent harbour. Biodegradation, 5(1):37-46. [doi:10. 1007/BF00695212]

Griffiths-Jones, S., Bateman, A., Marshall, M., et al., 2003. Rfam: an RNA family database. Nucleic Acids Res., 31(1): 
439-441. [doi:10.1093/nar/gkg006]

Hassanshahian, M., Zeynalipour, M.S., Musa, F.H., 2014. Isolation and characterization of crude oil degrading bacteria from the Persian Gulf (Khorramshahr provenance) Mar. Pollut. Bull., 82(1-2):39-44. [doi:10.1016/j.marpolbul. 2014.03.027]

Hazen, T.C., Dubinsky, E.A., DeSantis, T.Z., et al., 2010. Deep-sea oil plume enriches indigenous oil-degrading bacteria. Science, 330(6001):204-208. [doi:10.1126/ science.1195979]

Holmes, B., Popoff, M., Kiredjian, M., et al., 1988. Ochrobactrum anthropi gen. nov., sp. nov. from human clinical specimens and previously known as group $\mathrm{Vd}$. Int J. Syst. Bacteriol., 38(4):406-416. [doi:10.1099/0020771338-4-406]

Holt, J.G., Krieg, N.R., Sneath, P.H., et al., 1994. Bergey's Manual of Determinative Bacteriology, 9th Ed. Williams and Wilkins, Baltimore.

Jesubunmi, C.O., 2014. Isolation of oil-degrading microorganisms in spent engine oil-contaminated soil. J. Biol. Agric. Healthcare, 4(25):191-195.

Kavita, B., Keharia, H., 2012. Reduction of hexavalent chromium by Ochrobactrum intermedium BCR400 isolated from a chromium-contaminated soil. 3 Biotech, 2(1):79-87. [doi:10.1007/s13205-011-0038-0]

Kulkarni, G., Dhotre, D., Dharne, M., et al., 2013. Draft genome of Ochrobactrum intermedium strain M86 isolated from non-ulcer dyspeptic individual from India. Gut Pathog., 5:7. [doi:10.1186/1757-4749-5-7]

Kulkarni, G., Shetty, S., Dharne, M., et al., 2014. Genome sequencing analysis reveals virulence-related gene content of Ochrobactrum intermedium strain 229E, a urease-positive strain isolated from the human gastric niche. FEMS Microbiol. Lett., 359(1):12-15. [doi:10. 1111/1574-6968.12549]

Kumar, V., Singh, S., Manhas, A., et al., 2014. Bioremediation of petroleum hydrocarbon by using Pseudomonas species isolated from petroleum contaminated soil. Analysis, 30(4):1771-1776. [doi:10.13005/ojc/300436]

Lagesen, K., Hallin, P., Rødland, E.A., et al., 2007. RNAmmer: consistent and rapid annotation of ribosomal RNA genes. Nucleic Acids Res., 35(9):3100-3108. [doi:10.1093/nar/ gkm160]

Larkin, M.A., Blackshields, G., Brown, N., et al., 2007. Clustal $\mathrm{W}$ and Clustal $\mathrm{X}$ version 2.0. Bioinformatics, 23(21): 2947-2948. [doi:10.1093/bioinformatics/btm404]

Lincoln, S.A., Hamilton, T.L., Juárez, A.G.V., et al., 2015. Draft genome sequence of the piezotolerant and crude oil-degrading bacterium Rhodococcus qingshengii strain TUHH-12. Genome Announc., 3(2):e00268-e00315. [doi:10.1128/genomeA.00268-15]

Lowe, T.M., Eddy, S.R., 1997. tRNAscan-SE: a program for improved detection of transfer RNA genes in genomic sequence. Nucleic Acids Res., 25(5):955-964. [doi:10. 1093/nar/25.5.0955]

Marmur, J., Doty, P., 1962. Determination of the base composition of deoxyribonucleic acid from its thermal denaturation temperature. J. Mol. Biol., 5(1):109-118. [doi:10.1016/S0022-2836(62)80066-7]

Mata, J.A., Martínez-Cánovas, J., Quesada, E., et al., 2002. A detailed phenotypic characterisation of the type strains of Halomonas species. Syst. Appl. Microbiol., 25(3): 360-375. [doi:10.1078/0723-2020-00122]

Möller, L.V., Arends, J.P., Harmsen, H.J., et al., 1999. Ochrobactrum intermedium infection after liver transplantation. J. Clin. Microbiol., 37(1):241-244.

Mudshingkar, S., Choure, A., Palewar, M., et al., 2013. Ochrobactrum anthropi: an unusual pathogen: are we missing them? Indian J. Med. Microbiol., 31(3):306-308. [doi:10.4103/0255-0857.115664]

Pham, V.H., Kim, J., Jeong, S.W., 2014. Enhanced isolation and culture of highly efficient psychrophilic oildegrading bacteria from oil-contaminated soils in South Korea. J. Environ. Biol., 35(6):1145-1149.

She, Y.H., Zhang, F., Xia, J.J., et al., 2011. Investigation of biosurfactant-producing indigenous microorganisms that enhance residue oil recovery in an oil reservoir after polymer flooding. Appl. Biochem. Biotech., 163(2): 223-234. [doi:10.1007/s12010-010-9032-y]

She, Y.H., Wu, W.Q., Hang, C.C., et al., 2014. Genome sequence of Brevibacillus agri strain 5-2, isolated from the formation water of petroleum reservoir. Mar. Genomics, 18:123-125. [doi:10.1016/j.margen.2014.08.006]

Silva, D.S.P., de Lima Cavalcanti, D., de Melo, E.J.V., et al., 2015. Bio-removal of diesel oil through a microbial consortium isolated from a polluted environment. Int. Biodeter. Biodegr., 97:85-89. [doi:10.1016/j.ibiod.2014. 09.021]

Swain, M.T., Tsai, I.J., Assefa, S.A., et al., 2012. A post-assembly genome-improvement toolkit (PAGIT) to obtain annotated genomes from contigs. Nat. Protoc., 7(7):1260-1284. [doi:10.1038/nprot.2012.068]

Tamura, K., Stecher, G., Peterson, D., et al., 2013. MEGA6: molecular evolutionary genetics analysis version 6.0. Mol. Biol. Evol., 30(12):2725-2729. [doi:10.1093/molbev/ mst197]

Tatusov, R.L., Galperin, M.Y., Natale, D.A., et al., 2000. The COG database: a tool for genome-scale analysis of protein functions and evolution. Nucleic Acids Res., 28(1):33-36. [doi:10.1093/nar/28.1.33]

Tatusov, R.L., Natale, D.A., Garkavtsev, I.V., et al., 2001. The COG database: new developments in phylogenetic classification of proteins from complete genomes. Nucleic Acids Res., 29(1):22-28. [doi:10.1093/nar/29.1. 22]

Teyssier, C., Marchandin, H., Jean-Pierre, H., et al., 2005. Molecular and phenotypic features for identification of the opportunistic pathogens Ochrobactrum spp. J. Med. 
Microbiol., 54(10):945-953. [doi:10.1099/jmm.0.46116-0]

Velasco, J., Romero, C., López-Goñi, I., et al., 1998. Evaluation of the relatedness of Brucella spp. and Ochrobactrum anthropi and description of Ochrobactrum intermedium sp. nov., a new species with a closer relationship to Brucella spp. Int. J. Syst. Bacteriol., 48(3):759-768. [doi:10.1099/00207713-48-3-759]

Waranusantigul, P., Lee, H., Kruatrachue, M., et al., 2011. Isolation and characterization of lead-tolerant Ochrobactrum intermedium and its role in enhancing lead accumulation by Eucalyptus camaldulensis. Chemosphere, 85(4):584-590. [doi:10.1016/j.chemosphere.2011.06.086]

Yuan, Y., Lu, Z., Huang, L., et al., 2007. Biodegradation of nicotine from tobacco waste extract by Ochrobactrum intermedium DN2. J. Ind. Microbiol. Biotechnol., 34(8): 567-570. [doi:10.1007/s10295-007-0212-x]

Zerbino, D.R., Birney, E., 2008. Velvet: algorithms for de novo short read assembly using de Bruijn graphs. Genome Res., 18(5):821-829. [doi:10.1101/gr.074492. 107]

Zhang, F., She, Y., Chai, L., et al., 2012. Microbial diversity in long-term water-flooded oil reservoirs with different in situ temperatures in China. Sci. Rep., 2:760. [doi:10.1038/srep00760]

Zhang, F., Jiang, X., Chai, L., et al., 2014. Permanent draft genome sequence of Bacillus flexus strain T6186-2, a multidrug-resistant bacterium isolated from a deepsubsurface oil reservoir. Mar. Genomics, 18:135-137. [doi:10.1016/j.margen.2014.09.007]

Zheng, B., Zhang, F., Chai, L., et al., 2014. Permanent draft genome sequence of Geobacillus thermocatenulatus strain GS-1. Mar. Genomics, 18:129-131. [doi:10.1016/j. margen.2014.09.005]

Zhou, Y., Liang, Y., Lynch, K.H., et al., 2011. PHAST: a fast phage search tool. Nucleic Acids Res., 39(Suppl. 2): W347-W352. [doi:10.1093/nar/gkr485]

\section{中文概要}

题 目: 一株分离自地层水的石油降解菌的特性研究: Ochrobactrum intermedium 环境分离菌株与临床 分离菌株的比较基因组分析

目 的：对一株地层水分离的石油降解菌 Ochrobactrum intermedium 2745-2 进行生理生化特性的研究、全 基因组测序以及比较基因组研究。

创新点: 首次对一株分离自地层水的石油降解菌 O. intermedium 2745-2 进行了生理生化特性研究以及基 因组测序, 从基因组角度解释菌株 2745-2 对石油 的降解能力。通过菌株 2745-2 与同种其他临床分 离菌株的比较基因组学分析, 表明 2745-2 仍具有 多种与致病性相关的基因。

方 法: 通过微生物富集培养的方法从油井的地层水中分 离石油降解微生物, 通过聚合酶链反应 (PCR) 扩增 16S 核糖体 RNA（rRNA）序列进行比较和 分析确定菌株的分类地位属于 O. intermedium

（图 1）。采用 Illumina HiSeq2000 对菌株 2745-2 进行高通量测序, 采用 Velvet 1.2.07 和 RAST server 分别进行数据组装和注释 (表 1)。PHAST 寻找基因组中的噬菌体相关序列（图 4 和表 2)。 通过 BLAST+和 BRIG 对环境分离菌株 (2745-2) 和临床分离菌株 (M86、229E 和 $\left.\mathrm{LMG} 3301^{\mathrm{T}}\right)$ 进 行基因组比较（表 3、表 4 和图 5）。

结 论：首次对一株环境分离的 O. intermedium (2745-2) 进行全基因组测序, 揭示具有多种与石油降解相 关的基因。通过环境分离菌株 (2745-2) 与临床分 离菌株 (M86, 229E 和 $\mathrm{LMG} \mathrm{M} 301^{\mathrm{T}}$ ) 的基因组比较 分析, 表明 2745-2 仍具有多种致病性相关的基因。

关键词: Ochrobactrum intermedium; 石油降解; 比较基因 组; 病原菌 